\title{
EFFECTS OF DREDGED SEDIMENT DISPOSAL ON THE COASTAL MARINE MACROBENTHIC ASSEMBLAGE IN SOUTHERN BRAZIL
}

\author{
ANGONESI, L. G., BEMVENUTI, C. E. and GANDRA, M. S. \\ Fundação Universidade Federal do Rio Grande - FURG, Laboratório de Ecologia de Invertebrados Bentônicos, \\ Departamento de Oceanografia, C. P. 474, CEP 96201-900, Rio Grande, RS, Brazil \\ Correspondence to: Luciana Garcia Angonesi, Fundação Universidade Federal do Rio Grande - FURG, \\ Laboratório de Ecologia de Invertebrados Bentônicos, Departamento de Oceanografia, Campus Carreiros, \\ C. P. 474, CEP 96201-900, Rio Grande, RS, Brazil, e-mail: luangonesi@ hotmail.com
}

Received March 15, 2004 - Accepted October 20, 2004 - Distributed May 31, 2006

(With 3 figures)

\begin{abstract}
The aim of this study was to evaluate the deposition impact of dredged material from Patos lagoon estuary on a benthic macroinvertebrate assemblage structure in an adjacent coastal marine area. Nine sampling stations were chosen at random in the disposal area, and nine others in the same way in an adjacent control area. Samples were collected at a $19 \mathrm{~m}$ depth before sediment disposal (11 July 2000), during dredging and disposal operations (25 Oct. 2000), and three months thereafter (24 Aug. 2001). Statistical analysis indicated that sampling periods presented similar characteristics in both the control and disposal sites. Disposal of dredged sediment from Patos lagoon had no detectable detrimental effects upon macrobenthic faunal assemblage at the dumping site. This result is attributed both to adaptation of resident biota to dynamic sedimentary conditions and to the fine estuarine sediment dredged, the dispersion of which in the water column might have minimized sediment deposition and consequent damage to the benthic fauna.
\end{abstract}

Keywords: dredge, environmental impact, Patos lagoon, coastal zone.

\section{RESUMO}

\section{Efeitos da deposição de material proveniente de dragagem sobre uma associação de} macroinvertebrados bentônicos na zona costeira do Sul do Brasil

Objetivou-se avaliar o impacto da deposição de material dragado proveniente da região estuarina da lagoa dos Patos sobre a estrutura da associação macrobentônica no sítio de deposição, situado no ambiente marinho costeiro adjacente à desembocadura da laguna. Nove estações de coleta foram sorteadas, tanto no sítio de deposição quanto na área controle adjacente. As amostras, a $19 \mathrm{~m}$ de profundidade, foram coletadas antes do início de deposição do sedimento (11/07/2000), durante as operações de dragagem e deposição (25/10/2000) e três meses após o encerramento das atividades de deposição do material dragado (24/08/2001). Análises estatísticas indicaram que áreas controle e sítio de deposição apresentaram características faunísticas similares dentro dos períodos amostrais. Não foram detectados efeitos prejudiciais da deposição do sedimento sobre a associação de macroinvertebrados bentônicos na área de depósito. Este resultado pode ser atribuído às características da biota residente que está, provavelmente, adaptada às condições da dinâmica sedimentar do local e também às características predominantemente finas do sedimento dragado que, ao dispersar-se na coluna d’água, minimizaram a deposição das frações mais finas e um eventual dano ao macrozoobentos.

Palavras-chave: dragagem, impacto ambiental, lagoa dos Patos, zona costeira. 


\section{INTRODUCTION}

Due to the relative immobility of most benthic organisms, sediment deposition from open-sea dredging may be more damaging to benthic macroinvertebrate communities than to any other member of the aquatic ecosystem, (Kennish, 1992; Clarke \& Warwick, 1994). Studies have demonstrated broad differences in disposal effects on the macrofauna, ranging from minimal (Van Dolah et al., 1984; Radenac et al., 1997; Roberts \& Forrest, 1999; Smith \& Rule, 2001) to significant community-structure changes (Rees et al., 1992; Harvey et al., 1998; Roberts et al., 1998), indicating that the potential environmental effects of each dredging project must be evaluated on a case-by-case basis (Harvey et al., op cit).

The Rio Grande Harbor is located in the estuarine region of Patos lagoon (southern Brazil). This huge coastal lagoon covers a $10,360 \mathrm{~km}^{2}$ area along the coastal plain of Rio Grande do Sul state. The estuarine region occupies the southern portion of the lagoon and corresponds to $10 \%$ of its total area. Commercial navigation needs coupled with inadequate water depth make frequent dredging necessary in the Rio Grande Harbor area. Thus, from July 2000 to May 2001, approximately $2,334,000 \mathrm{~m}^{3}$ of sediment were dredged from the harbor's navigation channel. The dredged sediment, which, in estuarine region channels is composed predominantly of silt, clay, and fine sand (Calliari, 1997), was deposited in a coastal region, adjacent to the estuarine mouth, in an approximately $3.6 \mathrm{~km}^{2}$ area located 10 nautical miles offshore at $19-20 \mathrm{~m}$ depths. This site is delimited by the coordinates: A (32 $14^{\prime} 200^{\prime \prime} \mathrm{S}$ and $\left.051^{\circ} 58^{\prime} 900^{\prime \prime} \mathrm{W}\right)$; B (32 $14^{\circ}$ $750^{\prime \prime} \mathrm{S}$ and $\left.051^{\circ} 58^{\prime} 200^{\prime \prime} \mathrm{W}\right)$; C $\left(32^{\circ} 15^{\prime} 700^{\prime \prime} \mathrm{S}\right.$ and $\left.052^{\circ} 00^{\prime} 070^{\prime \prime} \mathrm{W}\right)$; and D (32 $12^{\circ} 210^{\prime \prime} \mathrm{S}$ and $\left.052^{\circ} 00^{\prime} 010^{\prime \prime} \mathrm{W}\right)$. Due to the influence of the Patos lagoon outlet, this region suffers natural periodic disturbances from silt and clay deposition, which results in fine particle increase in relation to sand grains (Calliari \& Fachin, 1993). This area is also impacted by deposition of sediments dislodged by dredging, whose effects on the marine benthic macroinvertebrate community are not yet known.

The aim of the present study was to evaluate the impact of dredged material deposition on the composition and abundance of the macrobenthic invertebrates in a marine coastal disposal site.

\section{METHODS}

\section{Field sampling}

In the coastal marine zone nine sampling stations were randomly chosen in the disposal area, and others selected in the same way in an adjacent control area (Fig. 1). Samples, which were taken at depths of 19-20 m, were collected before sediment disposal (11 July 2000) within the target dumpsite (D1) as well as at the nine stations in the control area $(\mathrm{C} 1)$. During the disposal period, the samples were taken on 25 Oct. 2000 (D2 and C2) and three months after disposal operations (24 Aug. 2001) at the same nine stations (D3) as well as the nine stations in the control area (C3).

At each station one sample was taken with a $0.078 \mathrm{~m}^{2}$ Van Veen grab $(19 \times 41 \mathrm{~cm})$. Samples were screened with a $0.5 \mathrm{~mm}$ pore-size nylon screen and the retained material was fixed in $10 \%$ formalin in seawater. In the laboratory all macrobenthic fauna - before being preserved in $70 \%$ ethanol - were identified with the help of a stereomicroscope and a microscope to the lowest possible taxon.

In July and October 2000, in the same area in which the biological samples were collected additional samples were collected to examine textural characteristics of area sediment. Grain-size structure was determined by the Geochemistry Laboratory of the Geosciences Department, FURG.

\section{Data analysis}

For each sampling station, species richness (expressed in number of species), density (expressed in number of individuals $/ 0.078 \mathrm{~m}^{2}$ ), abundance of individuals, the Shannon-Wiener (H') $\left(\log _{\mathrm{e}}\right)$ diversity index, and the Pielou evenness index $(\mathrm{J})$ were determined for each biological sample.

The densities of some of the species (those appearing to be more abundant in control or dumpsites, or vice-versa) were compared through a 1-way analysis of variance. Multivariate analyses were carried out for objectively identifying spatial changes in composition and abundance of the macrobenthic invertebrate communities (MDS, ANOSIM). The statistical analysis was carried out on $\log$-transformed data $(\log (\mathrm{x}+1))$ using the BrayCurtis similarity index. Statistical analysis was performed using a Primer 5.0 computer package 


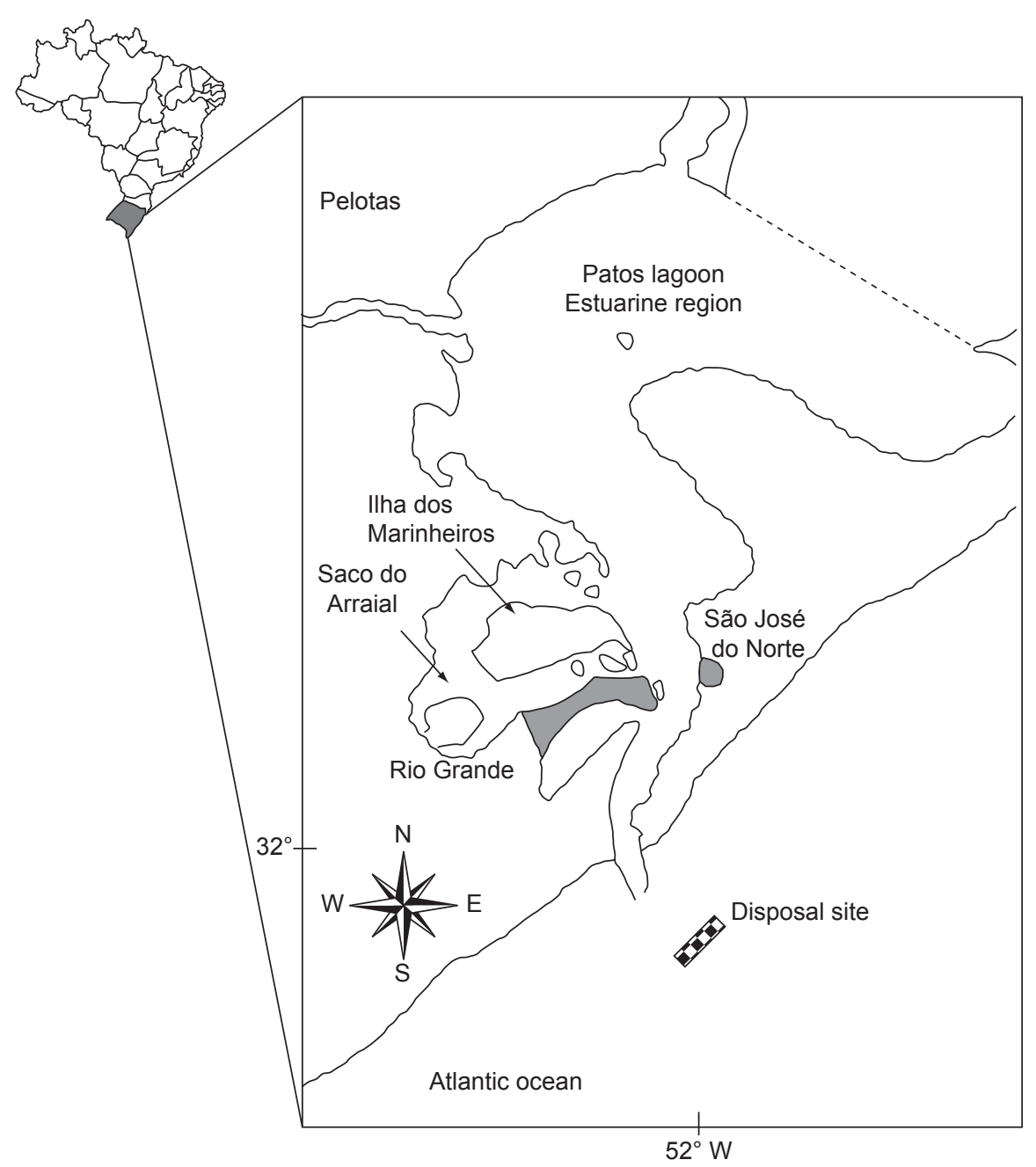

Fig. 1 - Location of the study area in the southern coast of Brazil.

(Plymouth Marine Laboratory) and Statistica ${ }^{\circledR} 98$ edition.

\section{RESULTS}

Bottom sediments sampled at the disposal site immediately before sediment disposal consisted mainly of a high silt and clay proportion. Sediment sampled during dumping operations at the same site showed an increase of the gravel and sand proportion (Table 1).

Table 2 represents the most abundant taxa (mean density in a $0.078 \mathrm{~m}^{2}$ area), which accounted for more than $90 \%$ of the total abundance in each temporal sample. Fig. 2 shows basic descriptive variables for macrofaunal samples from controls
(C) and dumping areas (D), with mean values and standard deviation of each variable.

Species richness displayed low variation between controls and the disposal sites (Fig. 2a). Mean values varied between 12 and 16 species in all sampling periods. Mean macrobenthic densities also showed similar values between control areas $\left(\mathrm{C} 1-55 \mathrm{ind} / 0.078 \mathrm{~m}^{2}\right.$; $\mathrm{C} 2-49 \mathrm{ind} / 0.078 \mathrm{~m}^{2}$; and $\mathrm{C} 3$ - $58 \mathrm{ind} / 0.078 \mathrm{~m}^{2}$ ) and dumpsite areas (D1 - 76 ind $/ 0.078 \mathrm{~m}^{2}$; D2 - 62 ind $/ 0.078 \mathrm{~m}^{2}$; and D3 - 63 ind $/ 0.078 \mathrm{~m}^{2}$ ) (Fig. 2b).

Shannon diversity index $\left(\mathrm{H}^{\prime}\right)$ was similar between control and dumpsites (Fig. 2c). In predisposal sampling, the mean values were 2.11 at $\mathrm{C} 1$ and 2.40 at D1; during disposal 2.10 was registered 
TABLE 1

Summary of the main sediment characteristics at each sampling period (Baisch et al., 2000).

\begin{tabular}{|l|c|c|c|c|}
\cline { 2 - 5 } \multicolumn{1}{c|}{} & \multicolumn{4}{c|}{ Granulometric fractions (mean values) } \\
\cline { 2 - 5 } \multicolumn{1}{c|}{} & $\mathbf{2} \mathbf{~ m m} \%$ & Sand \% & Silt \% & Clay \% \\
\hline Pre-Dump & 0.086 & 18.03 & 42.45 & 39.44 \\
\hline During Dumping & 0.29 & 34.06 & 38.18 & 27.47 \\
\hline
\end{tabular}

TABLE 2

Mean density (per grab area) and standard error (SE) of the most abundant taxa, which accounted for more than $90 \%$ of the total abundance in each temporal sample.

\begin{tabular}{|c|c|c|c|c|c|c|c|c|c|c|c|c|}
\hline & C1 & SE & D1 & SE & $\mathrm{C2}$ & SE & D2 & SE & $\mathrm{C3}$ & $\mathbf{S E}$ & D3 & SE \\
\hline \multicolumn{13}{|l|}{ Polychaeta } \\
\hline Armandia sp. & 0.1 & 0.1 & 1.2 & 0.9 & $*$ & - & $*$ & - & $*$ & - & $*$ & - \\
\hline Axiothella brasiliensis & 0.1 & 0.1 & 0.3 & 0.2 & 1.2 & 1.0 & 0.6 & 0.2 & $*$ & - & $*$ & - \\
\hline Capitella capitata & 1.3 & 0.9 & 0.8 & 0.6 & $*$ & - & $*$ & - & $*$ & - & $*$ & - \\
\hline Cirrophorus americanus & 4.2 & 1.1 & 6.8 & 1.8 & 3.6 & 1.2 & 12.1 & 2.0 & 10.9 & 3.7 & 22.8 & 11.0 \\
\hline Heteromastus similis & 2.7 & 1.7 & 1.3 & 0.7 & 0.8 & 0.5 & 0.6 & 0.3 & 0.6 & 0.5 & $*$ & - \\
\hline Hyalionecia sp. & $*$ & - & $*$ & - & 0.6 & 0.2 & 0.4 & 0.2 & $*$ & - & $*$ & - \\
\hline Kinbergonuphis sp. & 2.6 & 1.3 & 2.0 & 0.7 & 3.8 & 1.4 & 4.6 & 1.6 & 10.8 & 1.9 & 6.0 & 2.0 \\
\hline Magelona posterelongata & 2.1 & 1.0 & 4.9 & 1.7 & 1.9 & 0.7 & 5.0 & 1.6 & 0.1 & 0.1 & 1.9 & 1.0 \\
\hline Myriochele oculata & 4.9 & 2.5 & 10.2 & 4.3 & 0.3 & 0.2 & 0.6 & 0.2 & 1.2 & 0.6 & 1.4 & 0.6 \\
\hline Neanthes bruaca & 0.8 & 0.4 & 2.8 & 0.7 & 0.1 & 0.1 & 0.4 & 0.3 & 0.7 & 0.3 & 0.3 & 0.2 \\
\hline Ninoe brasiliensis & 1.0 & 0.4 & 1.6 & 0.7 & 1.9 & 1.0 & 0.7 & 0.2 & 4.6 & 2.6 & 0.6 & 0.3 \\
\hline Parandalia tricuspis & 2.2 & 0.8 & 6.2 & 1.9 & 3.3 & 0.9 & 4.6 & 0.8 & 4.0 & 0.8 & 2.4 & 0.6 \\
\hline Paraprionospio pinnata & 0.4 & 0.3 & 0.4 & 0.2 & 1.2 & 0.3 & 0.7 & 0.3 & 0.8 & 0.3 & $*$ & - \\
\hline Scoloplos rubra & 0.8 & 0.4 & 1.3 & 0.3 & 1.2 & 0.3 & 0.8 & 0.2 & 0.3 & 0.2 & 0.1 & 0.1 \\
\hline Sigambra grubei & 0.9 & 0.4 & 1.3 & 0.4 & 0.6 & 0.2 & 0.8 & 0.3 & 1.0 & 0.3 & 2.6 & 1.2 \\
\hline \multicolumn{13}{|l|}{ Crustacea } \\
\hline Diastylis sympterigiae & 0.6 & 0.3 & 1.3 & 0.6 & 0.1 & 0.1 & $*$ & - & $*$ & - & $*$ & - \\
\hline Gamaridea & 0.2 & 0.2 & 0.2 & 0.2 & 0.6 & 0.3 & 0.1 & 0.1 & 0.9 & 0.5 & 3.0 & 0.9 \\
\hline $\begin{array}{l}\text { Hemikalliapseudes } \\
\text { cavooreni }\end{array}$ & 11.3 & 4.0 & 12.4 & 1.7 & 3.8 & 0.7 & 5.2 & 1.6 & 9.8 & 4.7 & 6.1 & 1.7 \\
\hline Pinnixa patagoniensis & 1.1 & 0.6 & 1.1 & 0.5 & 1.1 & 0.9 & 2.6 & 2.3 & 1.6 & 0.7 & 3.4 & 2.1 \\
\hline \multicolumn{13}{|l|}{ Mollusca } \\
\hline Anachis isabellei & 5.0 & 1.2 & 5.8 & 1.2 & 4.1 & 1.0 & 3.6 & 1.3 & 1.6 & 0.6 & 1.0 & 0.5 \\
\hline Heleobia australis & $*$ & - & $*$ & - & 11.4 & 7.3 & 10.6 & 5.4 & $*$ & - & $*$ & - \\
\hline Mactra sp. & 0.1 & 0.1 & 0.7 & 0.4 & 0.6 & 0.3 & 0.6 & 0.3 & 0.2 & 0.1 & 0.3 & 0.2 \\
\hline Natica sp. & 7.7 & 1.6 & 7.2 & 2.0 & 3.8 & 1.3 & 4.4 & 1.2 & 0.1 & 0.1 & 1.0 & 0.4 \\
\hline Nemertina & 1.6 & 0.7 & 3.2 & 0.8 & 0.7 & 0.2 & 0.9 & 0.2 & 4.6 & 2.1 & 4.8 & 2.0 \\
\hline
\end{tabular}

* Specie's absence.

at $\mathrm{C} 2$ and 2.08 at D2; and in post-disposal samples the mean values reached 1.92 at $\mathrm{C} 3$ and 1.98 at D3. The Pielou evenness index $(\mathrm{P})$ followed the same patterns as those of the diversity index, with similar values between control and dumpsite samples.
In pre-disposal samples, benthic macrofaunal species composition was practically the same, with similar densities at C1 and D1 (Table 2), except for the higher densities of some species, e.g., the polychaetes Myriochele oculata (Oweniidae), 

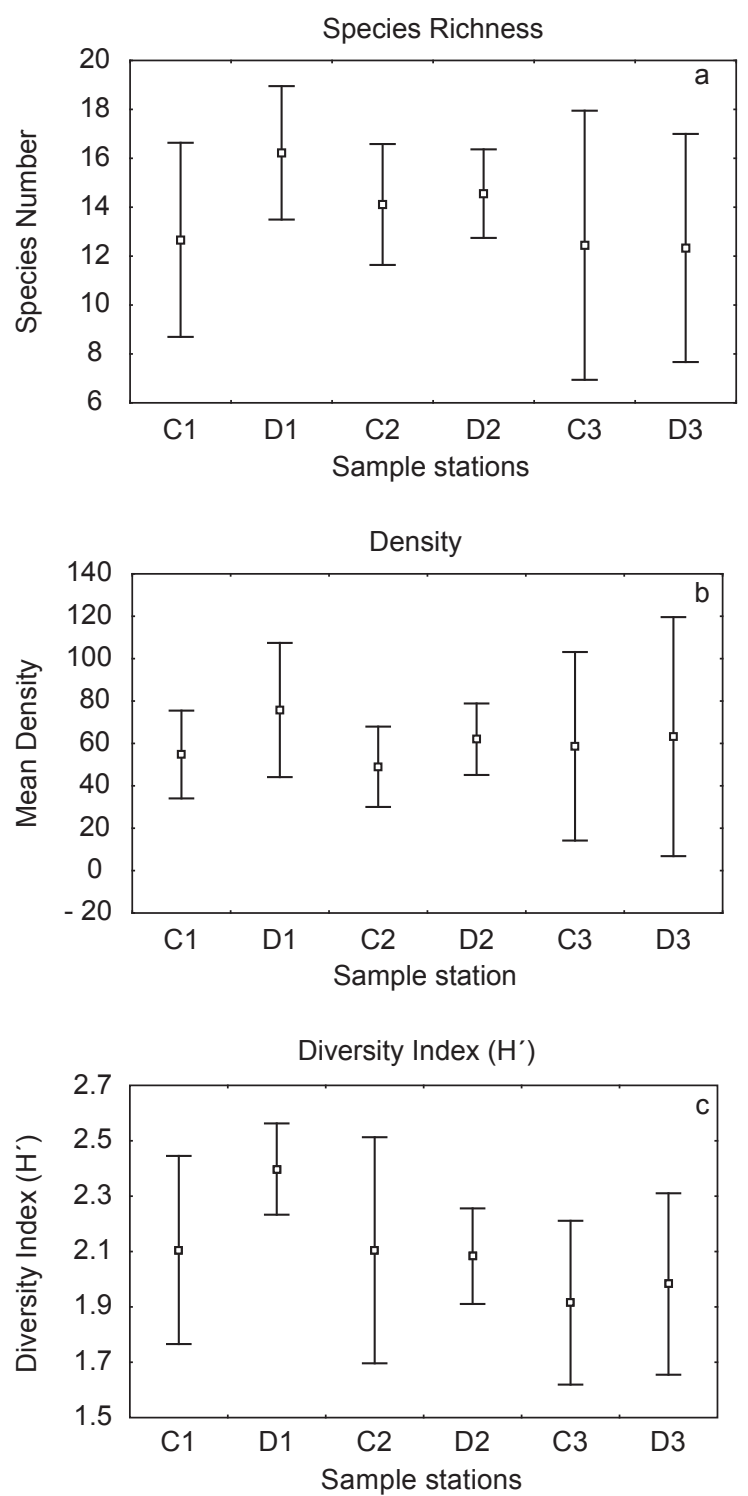

Fig. 2 - Basic descriptive variables for temporal macrofaunal samples (mean values and standard deviation). a) Species richness); b) mean density; and c) Shannon diversity index.

Parandalia tricuspis (Pilargidae) and Neanthes bruaca (Nereididae) (at least $>50 \%$ ) at the dumping area (D1). However, there was no significant statistical difference between the control area (C1) and pre-disposal site (D1) within the period that preceded the sediment disposal (ANOVA $p>0.05)$ due to the significant density variance in the samples.

During dredged sediment disposal, the gastropod species Heleobia australis was collected in the disposal site and also in the control area, whereas it had not been registered in the sampling prior to the dredged material disposal (C1 and D1). Other polychaete species, Cirrophorus americanus (Paraonidae) and Magelona posterelongata (Magelonidae), among a few other species, were found in higher densities at the dumpsite (D2). However, the standard deviation around the mean of each value showed that the densities were similar (ANOVA, $\mathrm{p}<0.05$ ). 
In post-disposal samples, the polychaete C. americanus densities remained high, mainly at the dumpsite (D3), but still without being statistically significant in relation to the control (C3). M. posterelongata and Sigambra grubei also presented higher densities (at least $>50 \%$ ) at the dumpsite, while Ninoe brasiliensis specimens were found in higher quantity in the control area. Similarly, the difference in density among C3 and D3 areas was not significant. In this period, only H. australis shells (without living organisms inside) were found.

The multi-dimensional scaling ordinations (MDS) and ANOSIM showed that the macrobenthic communities at both dumpsite and control areas were similar (Fig. 3). Samples from each site are spread throughout the plot (Fig. 3a, b, and c), though there is a tendency for samples to form groups with respect to the sampling periods (Fig. 3d). This temporal variability was statistically significant (ANOSIM).

\section{DISCUSSION}

Neither descriptive nor multivariate analytical methods used on the macrobenthic composition and abundance evidenced a distinction between controls, pre-disposal zones, and post-disposal zones. These analyses showed that control site samples, pre-disposal, and post-disposal target site samples were biologically similar.

At first glance, dumping operations would be considered detrimental, mainly through smothering, to macrobenthic faunal assemblages, but some studies have demonstrated that benthic asssemblages show broad variation in their responses to this kind of disturbance. At one extreme, a study developed in Anse à Beufilis (eastern Canada) showed that, in the wake of open-sea dumping, drastic changes occurred in the form of a decrease in density of less opportunistic families and a major increase in the density of families with the more opportunistic habits (Harvey et al., 1998). Jones (1986) observed

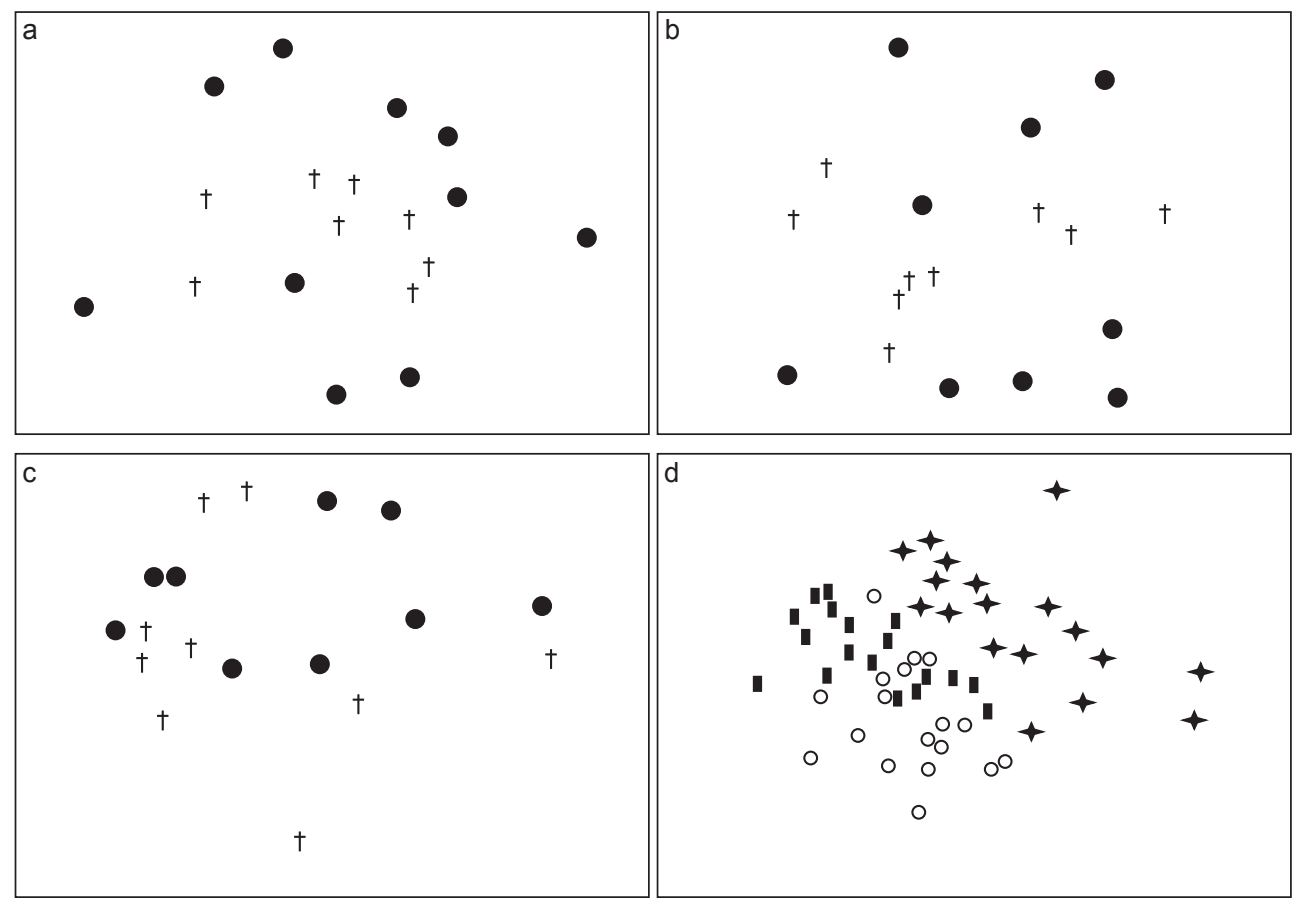

Fig. 3 - Two-dimensional MDS plot showing the relationship between control (filled circles) and dump zones (cross) in pre-disposal samples (a), during disposal (b) and post-disposal samples. Plot d represents the trend to temporal variability ( squares $=$ before; circles $=$ during; and large cross $=$ after sediment disposal). 
a decrease in species number after deposition, but a similar number of individuals when compared to that of the control site. However, some other studies have shown minimal (Van Dolah et al., 1984) or nondetectable effects of sediment deposition (Smith \& Rule, 2001). These last authors demonstrated that, even in a shallow area $(6 \mathrm{~m}$ depth), dredgespoil dumping at Park Beach (Australia) had no detectable short- or medium-term effects upon the infaunal community.

The impact of sediment disposal upon benthic communities varies depending on factors such as volume and sediment characteristics of the discharged material, water depth, surface and hydrography of the disposal area, types of organisms inhabiting the disposal area, and similarity of sediments in dredged and disposal areas, among others (Windom, 1976).

In this work, pre-disposal sampling at the dumpsite area showed the sediment type to be primarily silt-clay $(81.9 \%)$ with lesser percentages of sand (18\%) and gravel (0.086). During sediment disposal, the samples showed increased fractions of coarser sediment (Table 1). Baisch et al. (2000), after analyzing the sediment characteristics before and during dredged material disposal, observed that contents of metals, and dissolved organic carbon and nitrogen in the disposal site were similar in these two periods and remained within the range usually detected for that area.

During the present study it was registered that the current's flow speed was significant only in surface waters (between 0.42 to $0.46 \mathrm{~m} / \mathrm{s}$ ), whereas in deeper waters it was greatly reduced (< $0.05 \mathrm{~m} / \mathrm{s}$ ) (Möller et al., 2000). Thus, it is likely that fine dredged-sediment particles had already dispersed before hitting the seafloor, leaving to be deposited only gravel and sand. This fact was reinforced by the presence of the typically estuarine gastropod H. australis (Bemvenuti, 1997a) during operations in the disposal site (D2). In a finding that can be related to the ocean surface current, which may have changed the deposition route of the shells, this species was also found in the control site (C2) (Table 2), but not in several samplings from coastal region areas near the dumpsite studied here (Bemvenuti et al., 1978; Absalão, 1991). On the other hand, studies carried out in Patos lagoon estuarine region (Bemvenuti, 1997a, b; Bemvenuti
\& Netto, 1998; Rosa-Filho \& Bemvenuti, 1998; Bemvenuti et al., 1992) registered this species as dominant in the sublittoral, among 2 and $6 \mathrm{~m}$ isobaths, and at depths greater than $6 \mathrm{~m}$ in muddy sand bottoms in channel areas $\left(>40,000 \mathrm{ind} / \mathrm{m}^{2}\right)$.

Another factor relevant to similarity of macrobenthic assemblages between the disposal and control sites is that biota resident in the study area is influenced by the Patos lagoon outlet. According to Calliari \& Fachin (1993), the area 10$50 \mathrm{~m}$ deep suffers periodic disturbances due to silt and clay deposition through Patos lagoon runoff. To survive these conditions, resident animals need to be mobile and capable of withstanding local sedimentation rates (Smith \& Rule, 2001).

A number of studies in different types of soft-sediment habitat have shown that benthic invertebrates can migrate vertically through overlying sediment. Maurer et al. (1981a, b; 1982), through laboratory experiments with mollusk, crustacean, and polychaete species concluded that under certain conditions vertical migration can be a viable mechanism for recolonizing a dredgedumping site.

Such data suggest that the marine macrobenthic community under the influence of the Patos lagoon has a natural resistance to the sediment deposition, developed as a reaction to the conditions frequently found at the disposal site. For instance, some abundant groups and species recorded in this study, like the Oweniidae (Myriochele oculata), Paraonidae, and Magelonidae (Magelona posterelongata), among others, are considered opportunistic or resistant (Harvey et al., 1998; Hilbig \& Blake, 2000). According to Richardson et al., 1977, Magelona sacculata was unaffected by dredge material disposal by being an active species, capable of considerable migration over the sediment surface as well as rapid burrowing through the sediment.

We concluded that the disposal of dredged sediment from Patos Lagoon had no detectable detrimental effects on macrobenthic faunal assemblages in the study area. These results we attributed both to the resident biota being adapted to dynamic sedimentary conditions, and to the dumped estuarine sediment being predominantly fine, so that its dispersion in the water column might have minimized sediment deposition and consequent damage to the benthic fauna. 
Acknowledgments — The authors are grateful to Nilton Araújo de Abreu for help during field and laboratory activities, and to Dr. Paulo da Cunha Lana and Dr. Paulo César de Paiva for help in Polychaeta identification.

\section{REFERENCES}

ABSALÃO, R. S., 1991, Environmental discrimination among soft-bottom mollusc associations off Lagoa dos Patos, South Brazil. Cont. Shelf Sci., 32: 71-85.

BAISCH,P. R., MIRELAN, N., CALLIARI, L. J., HARTMANN, C., TOLDO JR, E., GRIEP, G. H., LIMA, G. P. \& DEMORE, J. P., 2000, Geoquímica dos sedimentos, pp. 48-92. In: M. L. Asmus \& A. J. Zamboni, Monitoramento ambiental da operação de dragagem de manutenção do Porto de Rio Grande: Relatório Final - fase 1. Rio Grande. Fundação Universidade federal do Rio Grande (FURG). 197p.

BEMVENUTI, C. E., 1997a, Benthic invertebrates, pp. 4346. In: Seeliger, U., Odebrecht, C. \& Castello, J. (ed.), Subtropical convergence marine ecosystem: the coast and the sea in the warm temperate southwestern Atlantic, Springer-Verlag, Berlin, Germany.

BEMVENUTI, C. E., 1997b, Unvegetated intertidal flats and subtidal bottoms, pp. 78-82. In: Seeliger, U., Odebrecht, C. \& Castello, J. (ed.), Subtropical convergence marine ecosystem: the coast and the sea in the warm temperate southwestern Atlantic, Springer-Verlag, Berlin, Germany.

BEMVENUTI, C. E. \& NETTO, S. A., 1998, Distribution and seasonal patterns of the sublittoral benthic macrofauna of Patos Lagoon (South Brazil). Rev. Brasil. Biol., 58(2): 211-221.

BEMVENUTI, C. E., CAPITOLI, R. R., \& GIANUCA, N.M., 1978, Estudos de ecologia bentônica na região estuarial da Lagoa dos Patos. II. Distribuição quantitativa do macrobentos infralitoral. Atlântica, 3: 23-32.

BEMVENUTI, C. E., CATTAENO, S. A. \& NETTO, S. A., 1992, Características estruturais da macrofauna bentônica em dois pontos da região estuarial da Lagoa dos Patos, RS, Brasil. Atlântica, 14: 5-28.

CALlIARI, L. J. \& FACHIN, S., 1993, Laguna dos Patos. Influência nos depósitos lamíticos costeiros. Pesquisas, 20(1): 57-69.

CALLIARI, L. J., 1997, Geological Setting, pp. 13-18. In: Seeliger, U., Odebrecht, C. \& Castello, J. (ed.), Subtropical convergence marine ecosystem: the coast and the sea in the warm temperate southwestern Atlantic, Springer-Verlag, Berlin, Germany.

CLARKE, K. R. \& WARWICK, R. M., 1994, Changes in marine communities: an approach to statistical analysis and interpretation. Natural Environmental Research Council, Plymouth, UK, 234p.

HARVEY, M., GAUTHIER, D. \& MUNRO, J., 1998, Temporal changes in the composition and abundance of the macrobentic invertebrate communities at dredged material disposal sites in the Anse à Beaufils, Baie des Charleurs, eastern Canada. Mar. Poll. Bull., 36(1): 41-55.

HILBIG, B. \& BLAKE, J., 2000, Long-term analysis of polychaete-dominated benthic infaunal communities in Massachusetts Bay, U.S.A. Bull. Mar. Sci., 67(1): 147-164.
JONES, A. R., 1986, The effects of dredging and spoil disposal on macrobenthos, Hawkesbury Estuary, N. S. W. Mar. Poll. Bull., 17(1): 17-20.

KENNISH, M. J., 1992, Ecology of estuaries: anthropogenic effects. CRC Press, Boca Rantom, 494p.

MAURER, D., KECK, R. T., TINSMAN, J. C. \& LEATHEM, W. A., 1981a, Vertical migration and mortality of benthos in dredged material: Part II - Crustacea. Mar. Envir. Res., 4: 299-319.

MAURER, D., KECK, R. T., TINSMAN, J. C. \& LEATHEM, W. A., 1981b, Vertical migration and mortality of benthos in dredged material: Part I - Mollusca. Mar. Envir. Res. 5: 301-317.

MAURER, D., KECK, R. T., TINSMAN, J. C. \& LEATHEM, W. A., 1982, Vertical migration and mortality of benthos in dredged material: Part III - Polychaeta. Mar. Envir. Res., 6: 49-68.

MÖLlER, O. O., SILVEIRA, A. M. P., \& FREITAS, A. C., 2000, Dinâmica das águas, pp. 96-100. In: Asmus, M. L. \& Zamboni, A. J. Monitoramento ambiental da operação de dragagem de manutenção do Porto de Rio Grande: Relatório Final - fase 1. Rio Grande. Fundação Universidade federal do Rio Grande (FURG), 197p.

RADENAC, G., MIRAMAND, P. \& TARDY, J., 1997, Search for impact of a dredged material disposal site on growth and metal contamination of Mytilus edulis (L.) in CharenteMaritime (France). Mar. Poll. Bull., 34(9): 721-729.

REES, H. L., ROWLATT, S. M., LIMPENNY, D. S., REES, E. I. S. \& Rolfe, M. S., 1992, Benthic studies at dredged material disposal sites in Liverpool Bay. Aquat. Envir. Monit. Rep., 28: 1-21.

RICHARDSON, M. D., CAREY, A. G. \& COLGATE, W. A., 1977, Aquatic disposal field investigations Columbia River disposal site, Oregon. Technical Reports, Waterways Experiment Station, US Army, 411p.

ROBERTS, R. D., GREGORY, M. R. \& FOSTER, M. A., 1998, Developing an efficient macrofauna monitoring index from an impact study - a dredge spoil example. Mar. Poll. Bull., 36(3): 231-235.

ROBERTS, R. D. \& FORREST, B. M., 1999, Minimal impact from long-term dredge spoil disposal at a dispersive site in Tasman Bay, New Zealand. N. Zea. Jour. Mar. Freshw. Res., 33: 623-633.

ROSA-FILHO, J. S. \& BEMVENUTI, C. E., 1998, Caracterización de las comunidades macrobentónicas de fondos blandos en regiones estuarinas de Rio Grande do Sul (Brasil). Thalassas, 14: 43-56.

SMITH, S. D. A. \& RULE, M. J., 2001, The effects of dredgespoil dumping on a shallow water soft-sediment community in the Solitary Islands Marine Park, NSW, Australia. Mar. Poll. Bull., 42(11): 1040-1048.

VAN DOLAH, R. F., CALDER, D. R. \& KNOTT, D. M., 1984, Effects of dredging and open-water disposal on benthic macroinvertebrates in a South Carolina estuary. Estuaries, 7: 28-37.

WINDOM, H. L., 1976, Environmental aspects of dredging in the coastal zone. CRC Critical Rev. Envir. Cont., 7: 91-109. 